\title{
Innovation systems research: an agenda for developing countries
}

\author{
Abiodun Egbetokun ${ }^{1}$, Adekemi Jessica Oluwadare $^{1 *}$, Blessing Funke Ajao ${ }^{1}$ and Oluseye Oladayo Jegede ${ }^{2}$
}

\author{
* Correspondence: \\ adekemijessica@gmail.com \\ ${ }^{1}$ National Centre for Technology \\ Management, lle-Ife, Nigeria \\ Full list of author information is \\ available at the end of the article
}

\begin{abstract}
The continued relevance of the systems approach to the study of innovation, especially in developed countries, has been the subject of recent discourses. This paper argues that with respect to developing countries, discussions on innovation systems are yet to be exhausted. Against this background, the paper takes an objective look at the innovation systems approach and suggests an agenda for studying innovation systems in developing countries. The position of the paper is that modifications to the innovation systems approach present viable opportunities for understanding the innovation process in the developing world. Some concrete modifications, and their implications for future research, are proposed.
\end{abstract}

Keywords: Innovation system, Developing countries, Research agenda, Networks, Collective action

\section{Background}

"If I look back to the first mention of innovation systems in the literature and then just plot using Google Scholar, the number of articles that use innovation systems in the title, what you can see is, friends, this is a declining industry. We had a point where it diffused, it took off, there was a rapid ascension as it gained acceptance but now it's no longer a promising line of research." (Maryann Feldman, 2013). ${ }^{1}$

"Our goal is to convince you that it's [the innovation systems approach] not only promising but it remains exciting and useful. I believe innovators are embedded within and shaped by socio-political systems that grew through history and that there's still a lot of value to be gained by going in that direction." (Martin Kenney, 2013). ${ }^{2}$

This paper takes an objective look at the systems approach to the study of innovation and proposes an agenda for understanding the innovation processes in developing countries. Since Christopher Freeman first used the expression 'National System of Innovation' (NIS) in his 1982 OECD report-later published as Freeman (2004)-the systemic view of innovation has gained prominence in the literature. This point is aptly illustrated in Fig. 1.

The figure reports the result of an experiment similar to the one referenced by Maryann Feldman in the first of the opening quotes. We take a count of all Google Scholar articles published between 1982 and 2013 with innovation system in their title, and identify some seminal contributions along the timeline. The upward slope of the curve suggests that from a modest beginning, the innovation systems approach eventually diffused widely and

(c) The Author(s). 2017 Open Access This article is distributed under the terms of the Creative Commons Attribution 4.0 International License (http://creativecommons.org/licenses/by/4.0/), which permits unrestricted use, distribution, and reproduction in any medium, provided you give appropriate credit to the original author(s) and the source, provide a link to the Creative Commons license, and indicate if changes were made. 


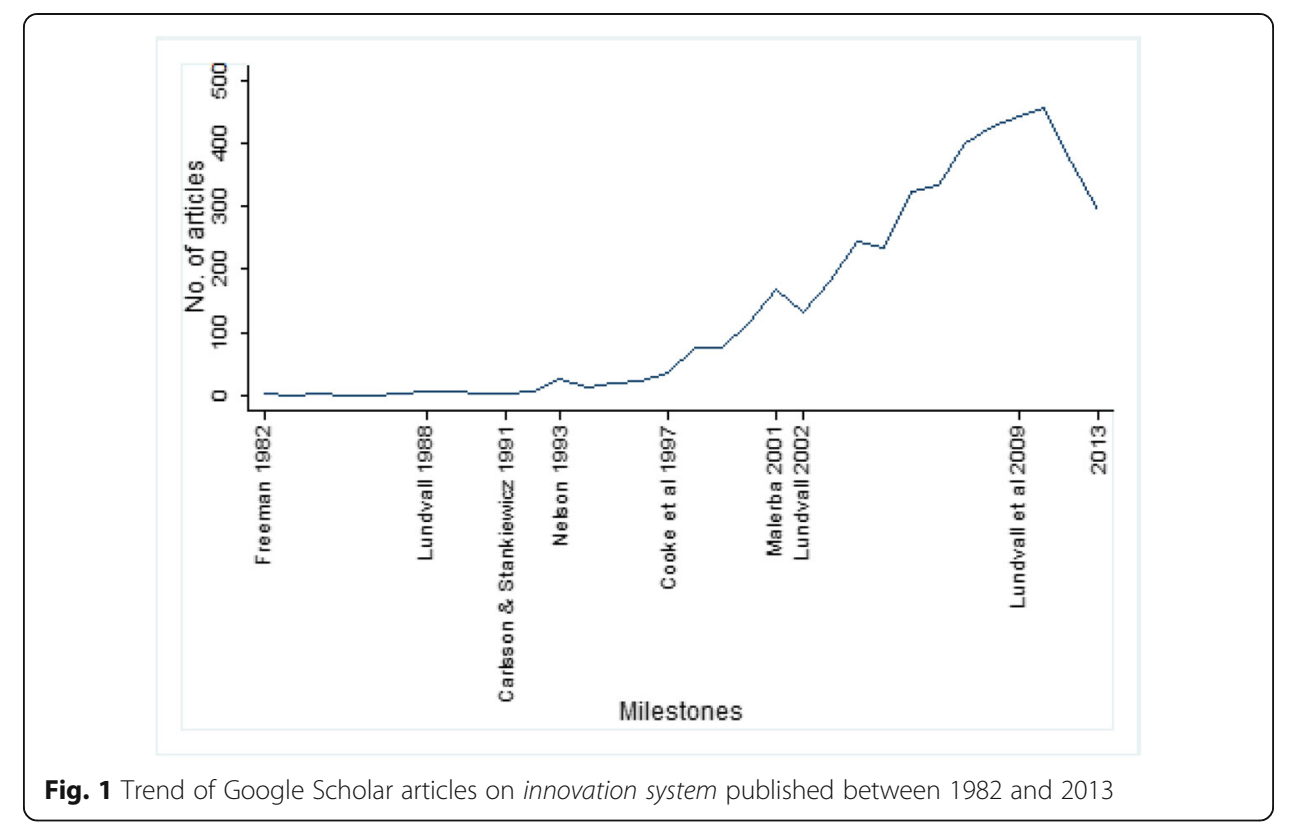

rapidly, an evidence of its research appeal. In fact, within the decade between 1991 and 2001, there was a take-off in the diffusion, driven by the emergence of several other concepts in addition to the original NIS concept. Each of the additional concepts focuses on a different level of analysis, including the technological (Carlsson and Stankiewicz, 1991), the regional (Cooke et al., 1997) and the sectoral (Malerba, 2002).

Nevertheless, the line in Fig. 1 is essentially an S-shaped diffusion curve with its peak around 2009-when the Handbook of Innovation Systems and Developing Countries (Lundvall et al., 2009) was released-followed by a sharp decline. This, as argued by Maryann Feldman in the first of the opening quotes, signals the end of what was once a breakthrough idea. In addition, we examine the number of published articles on innovation systems on ScienceDirect, ${ }^{3}$ between 2013 and 2017, what we see is that scholars are yet increasingly interested in the systems approach to innovation (Table 1). As clearly illustrated in the opening quotes, the continued relevance of the systems approach is the subject of an ongoing discussion.

As scholars wonder if the innovation systems approach has anything left to offer, particularly in the developed country context, we propose that modifications to the approach will reveal its usefulness in promoting and understanding innovation that solves societal challenges and improves welfare especially in less developed parts of the world.

Table 1 ScienceDirect Search Output

\begin{tabular}{ll}
\hline Year & Number of articles \\
\hline 2013 & 16,476 \\
2014 & 19,103 \\
2015 & 22,915 \\
2016 & 22,749 \\
2017 & 24,906 \\
\hline
\end{tabular}

Source: http://www.sciencedirect.com 
In light of the above, the important question that arises is: Are there modifications that can be made to the innovation systems approach to ensure its continued relevance particularly in developing countries where the innovation process is still poorly understood? In other words, are there aspects of the innovation systems approach that are yet to be explored? Some recent studies have already gone ahead in addressing this question. This stream of research draws attention to limitations of the innovation systems approach, recommending caution and certain modifications in its continued application in a globalised world (see, for instance, lizuka, 2013) and in developing countries (see, for instance, Sutz et al., 2013; Sutz and Cozzens, 2014). The present paper contributes to this growing stream of research.

Building upon recent scholarly work, this study identifies some gaps in the current innovation systems literature particularly concerning developing countries. Based on that, we suggest a number of conceptual and empirical issues for future research. Our entire discussion is cognizant of the specificities of the learning and capability accumulation processes in developing countries. In most of these countries, institutions are weak and systemic interactions are largely absent or, when present, rather weak. Even in the wake of the concept of open innovation, which emphasizes a more participatory and more distributed approach to innovation (Chesbrough, 2011), industry-academia research collaborations in developing countries are still weak. Although, firms in developing countries stand to benefit immensely from practicing open innovation, Sag et al. (2016) suggests that little is known about open innovation in developing countries. In addition, the innovation process in developing countries faces huge constraints and its outputs are far away from the global frontier (Hadjimanolis, 2000; Niosi, 2010; Oyelaran-Oyeyinka, 2006). Keeping these in mind, we hope that the issues raised in this paper will spur a wave of rigorous history-rich and context-friendly studies that will demonstrate the continued relevance of the systems approach to the study of innovation.

In the next section, we present the definition of innovation system adopted in this paper. The usefulness of the definition is illustrated with a brief comparison of the different innovation systems concepts as well as of developed and developing country systems. This is followed with a discussion of issues for future research. As part of the proposed research agenda, we highlight the fact that most analyses of innovation systems pay attention to the relatively well-known and formalised actors at the aggregate level. Consequently, not only is the informal sector underrepresented, the high levels of aggregation blurs the theoretical views and blunts the precision of empirical propositions based on existing studies. We also draw attention to a crucial omission in the innovation systems literature-the role of private institutions and collective action (networks) in overcoming innovation constraints. The final section contains some concluding thoughts.

\section{Innovation systems - An operational definition}

Much attention has been paid in previous literature to some of the historical features as well as evolutionary trajectory of the systems framework. ${ }^{4}$ Therefore, the emphasis in this paper is on how the existing limitations of the innovation systems approach offer opportunities for future research. Before turning to that discussion in the next section, we first outline here the view of an innovation system that we adopt in this 
paper. In general, an innovation system is a focusing device-some sort of analytical tool-which enables the analyses and understanding of the innovation process (taking into account learning and interaction among economic agents) with the aim of finding out which institutional configurations best support strong dynamic economic performance (Lundvall et al., 2009). This definition is attractive for two important reasons. Firstly, it transcends constraints imposed by varying levels of analysis. In particular, whether a sectoral, regional or national perspective is adopted, the generic aim of any study of innovation systems would be to understand what works and what does not, in the interest of economic development. This largely explains why, when viewed closely, the various innovation systems concepts do not differ significantly except in their theoretical bases and units of analysis (Table 2). Common to all the innovation system concepts is the centrality of knowledge as a vital resource for innovation and also the creation, diffusion and use of innovation. They all examine the various dimensions to the relationships among knowledge-generating and knowledge-utilising institutions within each system. Secondly, the above definition of an innovation system acknowledges an important feature of the mechanics of economic development and institutional contexts. Therefore, what already works somewhere may not work elsewhere. Ultimately, a veritable aim of innovation system research should be to find out the conditions under which innovation occurs, given a certain macroeconomic context. In this regard, developing countries are expected to differ significantly from developed countries. To illustrate this, we highlight in Table 3 some general characteristics of innovation systems in developed countries and contrast them with developing

Table 2 Comparing and contrasting the main innovation systems approaches

\begin{tabular}{|c|c|c|c|c|}
\hline & NIS & RIS & SIS & TIS \\
\hline $\begin{array}{l}\text { Foundational } \\
\text { Contributions }\end{array}$ & $\begin{array}{l}\text { Adam Smith (1776), } \\
\text { Freeman (1987), } \\
\text { Lundvall (1992), }\end{array}$ & Cooke et al. (1997) & Malerba (2002) & $\begin{array}{l}\text { Carlsson and } \\
\text { Stankiewicz 1991) }\end{array}$ \\
\hline $\begin{array}{l}\text { Theoretical } \\
\text { Elements }\end{array}$ & $\begin{array}{l}\text { National Production } \\
\text { Systems, Home-market } \\
\text { theory of International } \\
\text { trade, } \\
\text { Innovation as an } \\
\text { interactive process, } \\
\text { Role of institutions }\end{array}$ & $\begin{array}{l}\text { Evolutionary } \\
\text { economics } \\
\text { Economic } \\
\text { geography/regional } \\
\text { science } \\
\text { Institutional } \\
\text { economics (at least } \\
\text { in defining regions) } \\
\text { Heavy reliance on } \\
\text { NIS }\end{array}$ & $\begin{array}{l}\text { Evolutionary } \\
\text { economics } \\
\text { Industrial } \\
\text { organisation, } \\
\text { Industry life cycle, } \\
\text { Development blocks }\end{array}$ & $\begin{array}{l}\text { Neo-Schumpeterian } \\
\text { evolutionary } \\
\text { economics, } \\
\text { Institutional } \\
\text { emphasis, } \\
\text { Competences }\end{array}$ \\
\hline $\begin{array}{l}\text { Geographical } \\
\text { Focus }\end{array}$ & National boundaries & $\begin{array}{l}\text { Sub- national } \\
\text { regions(originally); } \\
\text { now shifting to } \\
\text { supranational }\end{array}$ & Focus on Sectors & $\begin{array}{l}\text { Focus on networks } \\
\text { of agents involved in } \\
\text { technology } \\
\text { dynamics }\end{array}$ \\
\hline Main Actors & $\begin{array}{l}\text { Knowledge creating } \\
\text { agents such as } \\
\text { universities, political } \\
\text { institutions, Industry }\end{array}$ & $\begin{array}{l}\text { Industrial Clusters, } \\
\text { knowledge } \\
\text { institutions }\end{array}$ & $\begin{array}{l}\text { Firms, knowledge } \\
\text { institutions }\end{array}$ & Firms \\
\hline Known Issues & $\begin{array}{l}\text { Applicability of the NIS } \\
\text { approach in developing } \\
\text { countries; } \\
\text { Mapping NIS and } \\
\text { measuring knowledge } \\
\text { flows among academia, } \\
\text { state and industry. }\end{array}$ & $\begin{array}{l}\text { The definition of } \\
\text { what constitutes a } \\
\text { regional system of } \\
\text { innovation }\end{array}$ & $\begin{array}{l}\text { Sectoral variances in } \\
\text { innovation within and } \\
\text { across national } \\
\text { boundaries }\end{array}$ & $\begin{array}{l}\text { The dependence of } \\
\text { the TIS on the rate } \\
\text { of technological } \\
\text { change; } \\
\text { high uncertainty, } \\
\text { weak or absent } \\
\text { institutions; } \\
\text { lack of specific actors }\end{array}$ \\
\hline
\end{tabular}


countries. The information in the table suggests that developing country systems are less creative, less capable and are weaker in terms of connectedness. Following from these fundamental differences, it becomes straightforward to identify some important gaps in the existing literature especially regarding developing countries.

\section{Research agenda}

Following the distinction between developed and developing country systems just discussed, the study next highlights some key areas in which the extant systems research appears to be deficient. Admittedly, this is not an exhaustive discussion. Rather, it focuses on specific aspects that are influential in how innovation is perceived and analysed. In addition, the identified research areas sufficiently portray points at which innovation in developing countries diverges from what obtains in the developed world.

\section{Multidimensional view of innovation}

For a long time, due to the influence of the literature and data on developed countries, analyses of innovation were confined to technologically new products and processes. The traditional perception of innovation as comprising the development and application of new technologies has been criticized based on its exclusion of innovation in services and of the non-technological aspects of firm-level activities (Pereira and Romero, 2013; Schmidt and Rammer, 2007). In spite of the growing research on innovation, the relevance of non-technological innovation for developing country firms is yet underserved. A quick comparison using data from the Nigerian Innovation Survey and the Eurostat online database give a hint on the prevalence of non-technological innovation in developing countries. In 2008, the rate of marketing and organizational innovation in Nigeria was over $60 \%$ in contrast to only about 30\% in the EU-27 countries in 2010. Conversely, the rate of innovation in goods and services ranged between 40 and $50 \%$ in Nigeria. In the EU countries for which data was available, the average was $75 \%$ for new goods and 51\% for new services. About 59\% of Nigerian firms had process innovation in contrast to an average of $75 \%$ in the EU countries. Moreover, studies (e.g. Pereira and Romero, 2013; Schmidt and Rammer, 2007) have revealed the importance and complementary nature of non-technological innovation to technological innovation.

Table 3 Comparing innovation systems in developed and developing countries

\begin{tabular}{|c|c|c|}
\hline Dimension & Developed context & Developing Context \\
\hline $\begin{array}{l}\text { Learning and } \\
\text { interactions among } \\
\text { economic agents }\end{array}$ & Active, strong, dense & Passive, weak and fragmented \\
\hline S\&T capabilities & $\begin{array}{l}\text { Boundless, Ease in technology absorption, } \\
\text { High levels of scientific training }\end{array}$ & $\begin{array}{l}\text { Limited, Difficulty in technology absorption, } \\
\text { Low levels of scientific training }\end{array}$ \\
\hline $\begin{array}{l}\text { Main knowledge } \\
\text { sources }\end{array}$ & Localized & Foreign \\
\hline $\begin{array}{l}\text { Nature of } \\
\text { innovative output }\end{array}$ & $\begin{array}{l}\text { Formal and active, Leaders, Radical and } \\
\text { Creative, High investments }\end{array}$ & $\begin{array}{l}\text { Mostly informal and passive, Followers, } \\
\text { Incremental and Imitative, Low investments }\end{array}$ \\
\hline $\begin{array}{l}\text { Industrial and } \\
\text { innovation policy }\end{array}$ & Strong intellectual property laws & Weak intellectual property laws \\
\hline $\begin{array}{l}\text { Economic and } \\
\text { business } \\
\text { environment }\end{array}$ & $\begin{array}{l}\text { Structured markets, high purchasing power } \\
\text { giving rise to strong domestic demand for } \\
\text { new high-tech products }\end{array}$ & $\begin{array}{l}\text { Large but unstructured markets, low } \\
\text { purchasing power giving rise to weak } \\
\text { domestic demand for technological } \\
\text { innovation }\end{array}$ \\
\hline
\end{tabular}


Studies on the measurement of innovation in the developing country context reveal certain implications for the innovation systems approach. One such implication is the non-inclusion of the learning and capacity building processes in developing economies, hence the absence of some relevant innovation indicators (Sutz, 2012). This is as a result of the uniqueness of the innovation activities in developing countries which sets them far from the frontiers of the innovation system approach as pioneered by developed countries. There is in fact, a multidimensional view of innovation that extends beyond innovation as an output of the R\&D investments of firms. The Oslo manual of 1997 explains innovation as technologically new or improved products and processes (OECD, 1997), appearing to exclude the non-technological aspects of innovation which are important to developing countries. Thankfully, however, the 2005 Oslo manual expanded the scope of innovation to include marketing and organisational innovations.

Beyond the scientific and technological outlook that innovation was traditionally defined to have, non-technological activities that lead to new and improved ways of doing things, generating both economic and social effects, have come under the innovation umbrella. Studies on innovation in developing economies reveal that innovative activities are not solely designed for high-tech environments (Bogliacino et al., 2009). It has thus become insufficient to view innovation only through the lens of new product development, process innovation and conventional R\&D (Pereira and Romero, 2013).

By way of distinguishing innovation in developed countries from innovation in developing countries, a strong R\&D capability and S\&T infrastructure is needed to acquire and develop the competences needed to operate on the technology frontier in the former, while in the latter, technological change mainly takes the form of acquisition of new machinery and imitation of the products and processes developed in advanced countries. Clearly, the acquisition and mastery of technologies developed elsewhere will play a crucial role in the innovation and development process of developing countries. ${ }^{5}$ Both technology adoption and imitation can spread rapidly among firms in emerging countries, with the benefits typical of catching-up processes. In the words of Fagerberg et al. (2010, p. 865), the "high-tech" approach to innovation which has framed much thinking and policy advice on the subject of innovation is strongly misleading when it comes to understanding the relationship between innovation and development."

\section{Competencies versus capabilities}

The concepts of competence and capability are founded upon the resource-based view (RBV) of the firm (Wernerfelt, 1984), which is a model that sees resources as key to superior organisational performance. RBV is an approach to achieving competitive advantage that emphasizes the importance of the competencies owned by an organisation in achieving competitive advantage. The terms 'competences' and 'capabilities' are widely used in the management literature, but often their use tends to be loose and nebulous (Saxena, 2014). Aderemi et al. (2011); Aderemi and Oyebisi (2012); Fagerberg et al. (2014); Siyanbola et al. (2012); Su et al. (2013) have delineated on technological capability and how it influences innovation. However, there is need to critically review what we actually mean as technological capability. The notion of technological capabilities is a central element in the innovation systems literature, especially in developing countries. A firm's capabilities is basically borne out of the resources it possesses. The types, amounts and the qualities of resources available to a firm have an important bearing on what the firm can do (Grant, 2001), and while resources refer to what an organization 
owns, capabilities refer to the organization's ability to create value from its resources. It is believed that by building their capabilities, latecomer firms can eventually evolve from being mere imitators to innovators. To build their capabilities, firms must engage in a process of technological learning in which interaction with knowledge- and information-bearing entities, such as universities and customers, plays crucial role (Bell and Pavitt, 1993). This is a very well-known argument in the latecomer capabilities literature, and it is central to the analysis of latecomer innovation systems.

However, much of the literature has not clearly distinguished between capabilities and competencies, which, though closely related, are not the same. It is, in fact, very common to see the terms 'capability' and 'competence' used synonymously in the literature. Therefore, many studies use proxies of both input (e.g., R\&D, human capital, acquisition of machinery and equipment) and output (e.g. new products or processes introduced by a firm) at the same time to represent capabilities. As Iammarino et al. (2008, p.1983) noted, '[a] major shortcoming of previous studies that have attempted to measure technological capabilities is that these latter are seen at the same time as inputs and outcomes...' Thus, the process by which firms in developing countries develop capabilities is much less understood than one would expect after decades of detailed case studies and within-country analysis.

Following von Tunzelmann (2009) what we advocate here is a perception of competencies as enablers of learning and capabilities as the outcome of the learning process which define the firm's performance. In fact, capabilities have been described by Dutta et al. (2005, p. 278) as "the efficiency with which a firm uses the inputs available to it (i.e., its resources, such as R\&D expenditure), and converts them into whatever output(s) it desires (i.e., its objectives, such as developing innovative technologies)". Prahalad and Hamel (1990) describe a firm's core competence as the collective learning or specialized knowledge in the organization, especially the capacity to coordinate diverse production skills and integrate streams of technologies. Barney (1991) sees a firm's unique competencies as the valuable, rare, imperfectly imitable and non-substitutable resources which invariably confer sustained competitive advantage on the firm. While a firm has core competencies at its disposal, its ability to gain and maintain competitive advantage based on these competencies depends on its capabilities. Whereas competencies may be acquired, a firm's capability is endogenously developed and shows up in its capacity to innovate by assimilating, exploiting and modifying acquired technologies, creating new technologies or developing new products and processes (Kim, 1997). This representation of capabilities echoes the distinction by Malerba and Orsenigo (2000, p. 297) between knowledge as an input in the production process and knowledge as the ability to actually produce new artifacts and knowledge. The former is largely codified and defines the range of what the firm knows while the latter is tacit and describes the range of what the firm is able to do.

It then follows that "since capabilities are an intermediate step between resources and outputs, one can hope to see the inputs that a firm uses and the outputs it achieves, but one can only infer its abilities in converting one to the other" (Dutta et al., 2005, p. 278). The methodological implication of this is that capabilities are better proxied by the technological and non-technological innovative activities of the firm (Iammarino et al., 2008, Iammarino et al., 2012). This is the same sense in which R\&D investments or percentage of highly qualified staff is taken as proxies for absorptive capacity, which 
enables firms to benefit maximally from open innovation. Note the use of the word 'proxied'. This is by no means a light-hearted connotation. Rather, it is to emphasize the idea that capabilities are intangible knowledge assets which cannot be observed directly but rather manifest in new products, processes or new business models. This would afford a more comprehensive understanding and reduce the indistinctness between capabilities and competencies.

\section{Formal versus informal linkages}

Another important aspect where a clear delineation of concepts would help to improve our understanding of the learning and innovation process, especially in developing countries, is the mode of interaction. No doubt, interactive learning is key for capability accumulation; but are all interactions destined to have similar effects? The answer to this, we argue, is not trivial. Formal interaction involves a collaboration agreement such as is concretized in contractual documents such as MoUs, technical agreements, JVs or joint R\&D agreements (Tether, 2002). By contrast, informal interaction means that an external source acts as source of information for innovation (Freitas et al., 2011). For instance, a firm may carry out joint R\&D with a university or another firm but it may also receive- voluntarily or involuntarily-information from them about a new technology. Either of these kinds of interaction might be enough for implementing an innovation (Garcia-Torres and Hollanders, 2009).

Previous researches such as Bernardes (2003); Intarakumnerd, et al. (2002); Oyelaran (2006); Oyewale (2005) have shown that there is weak interaction within the NIS in developing countries. However, the system might not be holistically weak. A lot of interactions take place between different actors that are not formal; a term referred to by Ajao and Jegede (2014) as 'off the record interaction'. Linkages and interactions could be informal and thus 'off the record', when industry participants and the academia, for instance meet in a conference or a forum and develop relationships which allow the free exchange of knowledge.

It is especially important in this context to underscore informal linkages as a source of networks in developing countries. Going by their definition, formal linkages will be relatively expensive given the resource constraints in developing countries. Besides, they are inherently very risky considering the weak legal infrastructure. As such, developing country actors will tend to form their linkages based on trust and in informal settings. Interpersonal relations rather than official communication often drive such interactions, and admittedly, much of it might even go unnoticed. For instance, in an extensive literature review, Freeman (1991) noted that informal networking is perhaps the most important in industry but it is rarely measured systematically. Ajao and Jegede (2014) also emphasized the need to clearly define what informal interaction should be, what indicators to show informal interactions and how it can be measured. In this sense, distinguishing between formal and informal interactions and conceptualising them as two distinct sources of networks will be useful to the understanding of the emergence and evolution of innovation systems in developing countries. To say the least, if we always look for formal networks only, many times we will find nothing and that might lead to the erroneous conclusion that networking is sparse in developing countries. 


\section{The informal sector}

The informal sector is essentially made up of economic and social activities outside the purview of the government. Until recently (see, for instance Cozzens and Sutz, 2012, and the special issue of Innovation and Development - Vol. 4, No.1), the informal sector was largely absent from the research agenda in innovation systems. The focus of the innovation system approach on the interaction process among firms, government and knowledge institutions has led to the marginalization of the interactions among non-firm and non-regulated institutions. The actors that are defined ex ante in innovation systems research are all in the formal sector and happen to be the more readily visible. Consequently, very little is known about how innovation takes place in informal settings. Substantial evidence exists on the level of innovativeness and hence productivity being generated by these informal organisations (Bhaduri and Sheikh, 2012; Müller, 2010; Daniels, 2010). ${ }^{6}$ In order to understand where innovation comes from and how it affects development, the informal sector must be well integrated into the research agenda. This sector has been discovered to be very large, generating significant social and economic benefits, and to include a significant portion of the population in developing countries. Studying innovation in the informal sector helps in an understanding of the role innovation plays in inclusive development. However, an associated problem with studying the informal sector is the absence of useful data on informal sector activities. Overcoming this and other challenges will require fresh approaches some of which Cozzens and Sutz (2014) nicely articulate. With particular reference to developing countries, greater attention is required to be given to innovation in the informal sector and caution must be applied in defining the system within which the actors in informal settings interact.

\section{Overly aggregated view}

Generally, analyses of innovation based on the systems approach are limited in the sense that, by definition, the approach relies on aggregation. Tiffin (1997) identified four key elements within the NIS, namely: Education and Research, Industrial Production, Finance, and Public Policy and Regulation. Each of the elements has some organisations or institutions that perform specific activities towards the actualisation of the overall objectives of the system. The convention is that every economic agent must fit within a clearly defined category, otherwise the systems approach is either not applicable or is considered inappropriate. For example, within the government element, there are many actors with different functions; while some are purely administrative, some are responsible for policy formulation, some enforce regulation, while some determine standards, others offer programmes and services to SMEs, etc. The pattern is similar for the knowledge elements, different actors perform different functions; some produce graduates, some purely do research while some carry out trainings, etc. Also, in the production element, some actors fall within the manufacturing environment while others are in the service environment: these actors perform varied duties. In the finance element, there are different actors, such as: the commercial banks which offer funds in exchange for collateral, development banks that offer funds at reduced cost, venture capitalist who invest in invention and in new businesses, etc. In particular, applying the NIS approach implies that the researcher will be looking for interactions between broad groups of actors within and across elements of the innovation system. The same goes for all the other versions of the systems approach. Thus, the theoretical lens offered by 
the systems approach is therefore somewhat blurred. For instance, a lot more is known in the innovation systems literature about the performance of system elements than about the sources of their heterogeneity. Needless to say, the heterogeneity of actor$\mathrm{s}$-another way of referring to the well-known evolutionary mechanism of variety-is a key determinant of aggregate dynamics. If knowledge about micro-level heterogeneity is so little, how then can explanations of aggregate performance be accurate? This is a view that is being taken up in recent discussions.

\section{The role of the state}

The factors that motivate and shape innovation efforts in an economy require a suitable environment in which to interact successfully. With the use of policies and an enabling environment, governments around the world are contributing significantly to the promotion of innovative activities within their economies. This can be attributed to the global acknowledgement of the role of technological change and innovation in economic growth and development. Government has a role to play in stimulating markets, providing infrastructure and education and giving companies incentives to invest in innovation (Johnson, 2000). Government, in both emerging and developed economies, have been adding new tax vehicles and reduction in trade barriers, among other incentives, to support modernization and innovation (PricewaterhouseCoopers, 2010). Regulation directly affects the innovative process (OECD, 1996) and the regulatory role of the government especially in a market economy is such that is irreplaceable.

A complete understanding of the innovation process requires a detailed examination of the impact of government actions in fostering innovation. The kind of analyses referred to here are of the kind reported in Mazzucato (2011) based on the experience in some developed countries. Studying the climate under which innovation efforts are stimulated and the ways by which government creates the right climate would provide deeper insights into the process of innovation and technical changes. Also, this may reveal the level of significance of government's influence on the other elements of the innovation system. Indeed, the literature on developing countries is heavily deficient in this regard.

\section{Role of private institutions in overcoming innovation constraints}

As far as innovation is concerned, one of the main differences between firms in developed and developing countries is the costly nature of innovation. In backward economies it is much more difficult to find sufficient financial, knowledge and institutional support for innovation (Schmitz, 1982). In the specific case of Nigeria, Biggs et al. (1995) noted that the context for manufacturing is of a harsh economic and institutional nature. One specific way in which firms make up for their resource deficiencies is networking and interactive learning. There is extensive evidence on the role of interactive learning in capability accumulation and firm-level innovation (Goedhuys, 2007; Lundvall, 1988; Oyelaran-Oyeyinka, 2005). Notwithstanding, a lot more is still to be understood about how these interactions emerge and their dynamics over time.

The existing evidence suggests that firms, for instance, form interactions for the sake of overcoming innovation obstacles. This begs two main questions: i) which specific actors are more relevant? and ii) how do firms go about the process of partner selection? Of course, it is known that interactions with market sources such as competitors, customers and suppliers are more prevalent, while research-industry interaction is weak. The persistent gap in knowledge is filled via the role of private institutions and 
collective action. If market sources are indeed the more important, then a rich mix of formal and informal interactions will occur in that context. Then, how are these interactions organized effectively to avoid conflicts of interest and to minimize redundancies? The answer, this study believes, lies in the extent to which the role of private institutions and collective action are understood. Private institutions in this sense refer to any form of arrangement outside the formal institutional structure, created by a set of economic actors for achieving a common aim. Industry associations that help to resolve conflicts and act as pressure groups are a good example of this. There is some evidence that such institutions are helpful in overcoming innovation obstacles in developing countries (Oyelaran-Oyeyinka, 2007). In Nigeria for instance, some notable private institutions have helped solve bottleneck problems in the production process. In the cable and wire sub-sector of the manufacturing sector, all the cable and wire manufacturing firms belong to the Manufacturers Association of Nigeria (MAN) which is the umbrella body for all industrial enterprises and industry associations in Nigeria. However, the Cable Manufacturers Association of Nigeria (CAMAN) is the private institution in the cable and wire manufacturing sub-sector to which firms in this subsector belong. As a private institution, MAN provides support for its member firms mainly by facilitating information flow through a members' database and regular meetings. The association also acts as a pressure group to protect members' interests. However, given the large and diverse membership of MAN, it is not always possible for it to provide micro-level or specialised support to individual firms (Egbetokun et al., 2009). Other examples of private institutions that contribute to the economic survival of firms in Nigeria are the Independent Petroleum Marketers Association of Nigeria (IPMAN) in the petroleum downstream sector, and the Computer and Allied Product Distribution Association of Nigeria (CAPDAN) in the ICT industry in Nigeria. Nevertheless, the precise mechanism through which they affect innovation is yet to be explored in research in least developed countries.

Another related perspective is the notion of collective action. By this, this study refers to the situation where the achievement of a desired outcome requires the efforts of multiple actors. In this context, social capital is fundamental, and self-organization is a crucial determinant of success (Ostrom, 1995). Indeed, viewing innovation as collective action in the context of development is not a far-fetched idea. Cozzens and Sutz (2014) already make eloquent arguments in that regard. What the study emphasizes here is the fact that obstacles to innovative actions in developing countries and how they are overcome will be much better understood by framing innovation as a collective action phenomenon. In fact, sometimes the action is so collective that one can begin to apply the idea of "commons" a la Hardin and Ostrom.

\section{From systems to networks and collective action}

Collective action bears close semblance to swarm intelligence in the field of AI and robotics. Swarm intelligence allows individuals in a system of robots to collectively build useful structures that are far more complex than any one of them could possibly build. This is possible because each individual is procedurally rational, that is, it has just enough information to take the next step without necessarily knowing what the others are doing or what the final outcome of their combined efforts will be. The individual's 
step may involve spotting and correcting previous errors or taking the next step in the evolution of solution to the task at hand. Given that information is limited, and as it were, each individual does not have a map, that is, they lack sufficient information to determine the project goal, how do interacting elements in the context of swarm intelligence build useful and purposeful structures? There are two reasons: information disclosure and adaptive learning. First, no individual takes a secret action. Though their thought processes are known only to themselves, their actions and the outcomes of those actions are fully observable. This information is taken as input by other elements, as well as those elements that come along on the same trajectory. These subsequent elements apply this input in taking a decision on what their next step should be: to move forward or step back to correct something. That is adaptive learning.

It is important to emphasize the role of private (individual) capabilities in this setting. The heterogenous learning capacity is crucial because even if the innovation problem is framed as a commons scenario, the performance differences that actors will exhibit in the medium- or long-run will be a direct function of their capabilities. Access to information (via commons) is one thing, exploiting and transforming this into knowledge is something else entirely.

Besides, the industry life cycle plays a role in the entire scheme of things. For instance, in the specific case of industry associations, at some point they transform from archetypal commons setup to some sort of club wherein exclusion criteria are applicable. How rapidly and when, if ever, this transformation will occur depends on industry trajectory and lifecycle. Closely related to the foregoing is the relevance of the macroeconomic environment. It can be argued that the innovation commons may be more intense where there are missing links in the macroeconomic environment. For instance, in the face of state failure, private actors might reciprocally see a common solution as the most efficient way of solving their innovation problems. Where there are no such macro challenges, perhaps it is more difficult to frame the innovation problem as a commons issue. This is indeed the basis for many industry associations in developing countries.

The Nigerian cable and wire manufacturing sector is an illustrative case. In a series of case studies described in detail elsewhere, it was found that some of the firms have made a private arrangement, effectively forming an industry association, which functions in a manner similar to what Robert Allen described as collective invention. This industry association has, in time, evolved into a sort of club in the sense that the facilities of any new manufacturer is inspected and certified by the association. When a plant fails this test, it is not admitted into the industry association (though the association lends technical support so failure is rare). Firms in the association freely share information through regular meetings of the CEOs and the Product Managers. The CEOs discuss management problems while the PMs discuss technical problems, to the point of exchanging product samples for peer laboratory testing. The feedback from this process, as Egbetokun et al. (2012) found out, is a key enhancer of the innovative capability of the member firms. Today, the product is the only domestic manufacture which is perceived by Nigerians to be superior to imports. The emergence of this group was necessitated by the fact that the manufacturers faced common problems: poor infrastructure - especially electricity, a weak domestic knowledge base and competition from cheap imports. 
Each actor being only procedurally rational uses available information to take the best possible decision. Since information accumulates because of full disclosure, then the quality of the adaptive decisions improve over time. There are two challenges: full information disclosure might mean inefficiency since there could be a lot of redundancy (arising from information overload) and errors (arising from cumulativeness). It will take a lot of time before agents observe and learn to overcome the problem of inefficiency. But once they do, they tend to limit information sharing. But how do they determine the socially optimal level of sharing? This is hard to determine and as such the system may evolve in the direction of persistent information overload or information deficit wherein there is too little information to permit cumulative progress. Either way, unless there is some coordination and regulation, the system is likely to evolve to become sub-optimally efficient. Herein lays the importance of strong institutions.

\section{Conclusion}

The implication clearly pointed out in this study is that scholars of the innovation systems approach are yet to explore all dimensions of this field, especially as it relates to developing countries. We thus posit, that the innovation systems approach remains a fruitful line of research. The study identified issues working against systems analysis and explored research agenda that would possibly make the systems analysis a promising line of research. The inclusion of non-technological innovation in the definition of innovation, especially in the context of developing countries which have viable service sectors driving their economies, would make the systems approach to innovation worthwhile in the near future. Also, the study dichotomizes competence from capability in empirical literature; most studies have used the two terms interchangeably leaving leading readers to draw erroneous inferences. Another new knowledge advanced in the paper is the importance of informal interactions in the innovation system. Previous studies have narrowly focused on formal interaction as the only possible form of interaction within the innovation system. The study further argued that the informal sector ought to be included as a major actor in the innovation system owing to the strategic role it plays in employment, production of goods and services, and their immense contribution to economic activity in developing countries. Another, pitfall in the innovation system approach addressed in the study is the aggregation of actors and stakeholders. Actors within each element play different roles; therefore interaction among broad range of actors across element smears the defined analysis of the innovation systems theory. In addition, the role of private institutions and collective action in overcoming innovation barrier is yet to be suitably explored in literature and is conspicuously missing in the innovation system approach. Scholars who wish to embark on future research in innovation systems, simply have to examine these peculiarities of innovation systems in developing countries as laid out in this paper, to uncover exciting and useful truths about the systems approach. These issues might well help to understand the challenges facing developing countries in 'catching up' with the developed world. The study concluded by proposing that for innovation systems theory to remain relevant in the near future there has to be a shift from systems to networks, i.e. network of actors within same element and across elements. 


\section{Endnotes}

${ }^{1}$ 35th DRUID Celebration Conference Debate on the motion 'Let it be resolved that this conference believes that the systems of innovation approach is no longer a promising line of research', held on 19th June, 2013, Barcelona, Spain. Videos available at https://vimeo.com/155650827

${ }^{2}$ Ibid

${ }^{3}$ http://www.sciencedirect.com/ search?qs=innovation $\% 20$ system \&show $=25 \&$ sortBy=relevance\&offset $=0$

${ }^{4}$ To give some representative examples: Carlsson et al. (2002) the basic elements as well as the analytical and methodological issues arising from various system concepts. In his introduction to the special issue of Industrial and Corporate Change on Building Innovation Systems, Niosi (2011) provides an overview of the history and components of innovation systems. Edquist (1997) discusses the emergence and characteristics of the various systems approaches. The first chapter of Lundvall et al. (2009) considers innovation systems in relation to economic growth and development. That chapter, drawing on Niosi (2002) and Cooper (1992), among others, also provides an excellent discussion of how innovation systems should be viewed in the context of development. In the Oxford Handbook of Innovation (Fagerberg et al., 2005), three chapters (7, 11 and 14 respectively) provide detailed discussions on the history and evolution of national, regional and sectoral innovation systems. Lundvall (2010) offers a comprehensive discussion on the history and potential future evolutionary direction of innovation systems research.

${ }^{5}$ How important a role technology diffusion plays in latecomer contexts is open to debate. On the one hand, there is the notion that a large proportion of innovative changes in latecomer economies derive from the adoption, diffusion and adaptation of imported technologies (BellandPavitt, 1993). On the other hand, it has recently been argued that technology adoption and diffusion may play a more limited role in driving innovation and growth in African manufacturing that is currently believed (Fafchamps and Söderbom, 2013)

${ }^{6}$ The informal sector comprises $48 \%, 51 \%, 65 \%$ and $72 \%$ of non-agricultural employment in North Africa, Latin America, Asia and Sub-Saharan Africa, respectively (ILO 2002). Micro Small and Medium Enterprises, account for over 60\% of GDP and over $70 \%$ of total employment in low income countries, while they contribute about $70 \%$ of GDP and $95 \%$ of total employment in middle income countries (NBS, 2010)

Acknowledgements

None.

Availability of data and materials

Not applicable.

Authors' contributions

Conception and design of study (AAE). Drafting of the manuscript ( $A A E, A J O, B F A, O O J)$. Revising manuscript critically for intellectual content (AAE). Approval of final version of manuscript (AAE, AJO, BFA, OOJ).

Funding

Not applicable.

Ethics approval and consent to participate

Not applicable. 
Consent for publication

Not applicable.

Competing interests

The authors declare that they have no competing interests.

\section{Publisher's Note}

Springer Nature remains neutral with regard to jurisdictional claims in published maps and institutional affiliations.

\section{Author details}

${ }^{1}$ National Centre for Technology Management, lle-Ife, Nigeria. ${ }^{2}$ African Institute for Science Policy and Innovation, Obafemi Awolowo University, lle-lfe, Nigeria.

Received: 17 May 2017 Accepted: 6 November 2017

Published online: 21 November 2017

\section{References}

Aderemi, H. O., \& Oyebisi, T. O. (2012). Management and evaluation of technological capability in ICT firms: An information system approach. International Journal of Business Information Systems, 11(2), 127-147.

Aderemi, H. O., Oyebisi, T. O., \& Adegbite, S. A. (2011). Hi-tech competence building in firms: Priority of technological efforts. IRCAB Journal of Social and Management Science, 1(1), 54-63.

Ajao, B.F \& Jegede, O.O (2014). Formal interactions versus informal interactions in the national innovation system: concept and issues.

Bell, M., \& Pavitt, K. (1993). Technological accumulation and industrial growth: Contrasts between developed and developing countries. Industrial and Corporate Change, 2(2), 157-210.

Bernardes, A. T. (2003). Cross-over, thresholds, and interactions between science and technology: Lessons for lessdeveloped countries. Research Policy, 32(5), 865-885,

Bhaduri, S. \& Sheikh, F.A. (2012). Measuring informal innovations: study of grasssroots innovation of Kashmir. Paper presented at the 9th Globelics academy in Tampere, Finland 2013.

Biggs, T., Shah, M. \& Strivastava, P. (1995). Technological capabilities and learning in African enterprises. World Bank technical paper no.288. http://siteresources.worldbank.org/EXTAFRSUMAFTPS/Resources/aft288.pdf accessed 14 December 2015.

Bogliacino, F., Perani, G., Pianta, M., \& Supino, S. (2009). Innovation in developing countries. The evidence from innovation surveys, Paper for the FIRB conference research and entrepreneurship in the knowledge-based economy. Milan: Bocconi University 7-8 September 2009.

Carlsson, B., \& Stankiewicz, R. (1991). On the nature, function and composition of technological systems. Journal of Evolutionary Economics, 1(2), 93-118.

Chesbrough, H. (2011). Everything you need to know about open innovation, Acessed online https:/www.forbes.com/sites/ henrychesbrough/2011/03/21/everything-you-need-to-know-about-open-innovation/\#4fffb84275f4 march, 2011.

Cooke, P., Gomez Uranga, M., \& Etxebarria, G. (1997). Regional innovation systems: Institutional and organisational dimensions. Research Policy, 26(5), 475-491.

Cozzens, S., \& Sutz, J. (2012). Innovation in informal settings: A research agendalDRC, Ottawa. https://www.idrc.ca/sites/ default/files/sp/Documents\%20EN/iid-framework-july-29.pdf . Accessed 8 Apr 2014.

Cozzens, S. \& Sutz, J. (2014). Innovation in informal settings: Reflections and proposals for a research agenda. Innovation and Development, 4(1), 5-31 (2014). doi:https://doi.org/10.1080/2157930X.2013.876803.

Daniels, S. (2010) Making do: Innovation in Kenya's informal economy. Analogue Digital.

Dutta, S., Narasimhan, O., \& Rajiv, S. (2005). Conceptualizing and measuring capabilities: Methodology and empirical application. Strategic Management Journal, 26(3), 277-285.

Edquist, C. (Ed.). (1997). Systems of Innovation. London: Frances Pinter.

Egbetokun, A., Adeniyi, A., \& Siyanbola, W. (2012). On the capability of SMEs to innovate: The cable and wire manufacturing sub-sector in Nigeria. International Journal of Learning and Intellectual Capital, 9(2), 64-85.

Egbetokun, A. A., Siyanbola, W. O., Sanni, M., Olamade, O. O., Adeniyi, A. A., \& Irefin, I. A. (2009). What drives innovation? Inferences from an industry-wide survey in Nigeria. International Journal of Technology Management, 45(1), 123-140.

Fafchamps, Marcel, \& MånsSöderbom."Network Proximity and Business Practices in African Manufacturing." The World Bank Economic Review (2013).

Fagerberg, J., Feldman, M. P., \& Srholec, M. (2014). Technological dynamics and social capability: US states and European nations. Journal of Economic Geography, 14(2), 313-337.

Fagerberg, J.; Srholec, M. \& Verspagen, B. (2010). Innovation and economic development. In H. Bronwyn, and N. Rosenberg (Eds.), Handbook of the Economics of Innovation (pp. 833-872). Elsevier.

Freeman, C. (1991). Networks of innovators: A synthesis of research issues. Research Policy, 20(5), 499-514.

Freitas, I. M. B., Clausen, T., Fontana, R., \& Verspagen, B. (2011). Formal and informal external linkages and firms' innovative strategies. A cross-country comparison. Journal of Evolutionary Economics, 21, 91-119.

Garcia-Torres, M. A. \& Hollanders, H. (2009). The diffusion of informal knowledge and innovation performance: A sectoral approach. UNU-MERIT working paper no. 2009-013. http://www.merit.unu.edu/publications/wppdf/2009/ wp2009-013.pdf. Accessed 13 May 2014.

Goedhuys, M. (2007). Learning, product innovation, and firm heterogeneity in developing countries; evidence from Tanzania. Industrial and Corporate Change, 16(2), 269-292.

Grant, R.M. (2001). The resource-based theory of competitive advantage. California Management Review.

Hadjimanolis, A. (2000). An investigation of innovation antecedents in small firms in the context of a small developing country. R\&D Management, 30(3), 235-246.

lammarino, S., Padilla-Pérez, R., \& von Tunzelmann, N. (2008). Technological capabilities and global-local interactions: The electronics industry in two Mexican regions. World Development, 36(10), 1980-2003. 
lammarino, S., Piva, M., Vivarelli, M., \& von Tunzelmann, N. (2012). Technological capabilities and patterns of innovative cooperation of firms in the UK regions. Regional Studies, 46(10), 1283-1301.

lizuka, M. (2013). Innovation systems framework: Still useful in the new global context. Innovations, 005.

Intarakumnerd, P., Chairatana, P., \& Tangchitpiboon, T. (2002). National innovation system in less successful developing countries: The case of Thailand. Research Policy, 31, 1445-1457.

International Labour Organisation (ILO), (2002). Women and men in the informal economy: A statistical picture. First Edition. http://www.wiego.org/sites/default/files/publications/files/LLO-Women-Men-Informal-2002.pdf . Accessed 26 Aug 2013

Jay Barney, (1991) Firm Resources and Sustained Competitive Advantage. Journal of Management 17 (1):99-120.

Johnson, A. (2000). Functions in innovation system approaches. https://www.researchgate.net/publication/253725869_ Functions_in_Innovation_System_Approaches. Accessed 27 Feb 2014.

Kim, L. (1997). Imitation to innovation: The dynamics of Korea's technological learning. Harvard: Harvard Business School Press.

Lundvall, B.-Å. (1988). Innovation as an interactive process: From user-producer interaction to the national system of innovation. In G. Dosi, C. Freeman, R. Nelson, G. Silverberg, \& L. Soete (Eds.), Technical change and economic theory (pp. 349-369). London: Pinter Publishers.

Lundvall, B. Å., Joseph, K. J., Chaminade, C., \& Vang, J. (Eds.). (2009). Handbook of innovation systems and developing countries: Building domestic capabilities in a global setting. Edward Elgar Publishing.

Lundvall, B.Å. (Ed.). (2010). National systems of innovation: Toward a theory of innovation and interactive learning (Vol. 2). Anthem Press.

Malerba, F. (2002). Sectoral systems of innovation and production. Research Policy, 31, 247-264.

Malerba, F., \& Orsenigo, L. (2000). Knowledge, innovative activities and industrial evolution. Industrial and Corporate Change, 9(2), 289-314.

Mazzucato, M. (Ed.). (2011). The entrepreneurial state. London: Demos.

Müller, J. (2010). Social construction of endogenous technology in the South. Paper for FAU Conference Workshop 4 on Community Entrepreneurs and Local Economic Development, Gjerrild, Grenaa, Djursland. March 2010.

National Bureau of Statistics (NBS) (2010). Survey report on micro, small and medium enterprises (MSMEs) in Nigeria. [online] 2010 National MSME Collaborative Survey. nigerianstat.gov.ng.

Niosi, J. (Ed.). (2010). Building national and regional innovation systems: Institutions for economic development. Cheltenham: Edward Elgar Publishing.

OECD (1996) Regulatory reform and innovation. http://www.oecd.org/sti/inno/2102514.pdf Accessed 14 December 2015.

OECD (1997) Proposed Guidelines for Collecting and Interpreting Technological Innovation Data-Oslo Manual second edition.

Ostrom, E. (1995). Self-organization and social capital. Industrial and Corporate Change, 4(1), 131-159.

Oyelaran-Oyeyinka, B. (2005). Inter-firm collaboration and competitive pressures: SME footwear clusters in Nigeria. International Journal of Technology and Globalisation, 1(3/4), 343-360.

Oyelaran-Oyeyinka, B. (Ed.). (2006). Learning to compete in African industry: Institutions and Technology in Development. Hampshire: Ashgate Publishing Coy.

Oyelaran-Oyeyinka, B. (2007). Learning in local systems and global linkages: The Otigba computer hardware cluster in Nigeria. In B. Oyelaran-Oyeyinka \& D. McCormick (Eds.), Industrial clusters and innovation systems in Africa. Tokyo: United Nations University Press.

Oyewale, A. A. (2005). Addressing the research-industry linkage impasse in Nigeria: The critical issues and implementation strategies. Paper presented at the 3rd international conference of the global network for the economics of learning, innovation and competence building systems (GLOBELICS) October 31-November 4, 2005. Tshwane University of Technology, Tshwane, South Africa.

Pereira, C. S., \& Romero, F. C. C. (2013). Non-technological innovation: Current issues and perspectives. Independent Journal of Management and Production, 4(1), 360-376.

Prahalad, C.K. and Hamel, G. (1990). The Core competence of the corporation, Harvard Business Review, may-June, 1990.

PricewaterhouseCoopers (2010). Government's Many Roles in Fostering Innovation. www.pwc.com/gx/en/technology/ pdf/how-governments-foster-innovation-2010.pdf

Sağ, S., Sezena, B., \& Güzel, M. (2016). Factors that motivate or prevent adoption of open innovation by SMEs in developing countries and policy suggestions, Procedia. Social and Behavioral Sciences, 235, 756-763.

Saxena, K.B. (2014). Capabilities versus Competence: How are they Different? Accessed online https://www. linkedin.com/pulse/20141123155439-7430899-capabilities-versus-competence-how-are-they-different Published on November 23, 2014.

Schmidt, T. \& Rammer, C. (2007) Non-technological and Technological Innovation: Strange Bedfellows? ZEW Discussion Paper 07-052.

Schmitz, H. (1982). Growth constraints on small-scale manufacturing in developing countries: A critical review. World Development, 10(6), 429-450.

Siyanbola, W., Egbetokun, A., Adebowale, B. A., \& Olamade, O. (Eds.). (2012). Innovation Systems and Capabilities in Developing Regions. Gower.

Su, Z., Peng, J., Shen, H., \& Xiao, T. (2013). Technological capability, marketing capability, and firm performance in turbulent conditions. Management and Organization Review, 9(1), 115-137.

Tether, B. (2002). Who co-operates for innovaton, and why? An empirical analysis. Research Policy, 31, 947-967.

Tiffin, S. (1997). Building science and technology innovation systems in Africa. Paper delivered at the 1st First Regional Workshop on The Restructuring of National Science and Technology Systems in Africa, Regional Programme for Technology Management, Lagos, May 12-16, 1997.

von Tunzelmann, N. (2009). Competencies versus capabilities: A reassessment. Economia Politica 26(3), 435-464.

Wernerfelt, B. (1984). A resource-based view of the firm. Strategic Management Journal, 5(2), 171-180. 